University of Denver

Digital Commons @ DU

Fuel Efficiency Automobile Test Publications Fuel Efficiency Automobile Test Data Repository

2012

\title{
Emission Changes Resulting from the San Pedro Bay, California Ports Truck Retirement Program
}

\author{
Gary A. Bishop \\ University of Denver, gbishop@du.edu \\ Brent G. Schuchmann \\ University of Denver, schuchb@gmail.com \\ Donald H. Stedman \\ University of Denver \\ Douglas R. Lawson \\ National Renewable Energy Laboratory
}

Follow this and additional works at: https://digitalcommons.du.edu/feat_publications

Part of the Environmental Chemistry Commons

\section{Recommended Citation}

Bishop, G. A.; Schuchmann, B. G.; Stedman, D. H.; Lawson, D. R. (2012) Emission Changes Resulting from the San Pedro Bay, California Ports Truck Retirement Program. Environ. Sci. Technol. 46, 551-558. DOI: $10.1021 /$ es202392g.

\section{(c) (1) (8)}

This work is licensed under a Creative Commons Attribution-NonCommercial 4.0 International License This Article is brought to you for free and open access by the Fuel Efficiency Automobile Test Data Repository at Digital Commons @ DU. It has been accepted for inclusion in Fuel Efficiency Automobile Test Publications by an authorized administrator of Digital Commons @ DU. For more information, please contact jennifer.cox@du.edu,digcommons@du.edu. 


\title{
Emission Changes Resulting from the San Pedro Bay, California Ports Truck Retirement Program
}

\author{
Gary A. Bishop*, Brent G. Schuchmann and Donald H. Stedman \\ Department of Chemistry and Biochemistry \\ University of Denver, Denver, Colorado 80208
}

Douglas R. Lawson

National Renewable Energy Laboratory

Golden, CO 80401

*To whom correspondence should be made; email: gbishop@du.edu

\begin{abstract}
Recent US EPA emissions regulations have resulted in lower emissions of particulate matter and oxides of nitrogen from heavy-duty diesel trucks. To accelerate fleet turnover the State of California in 2008 along with the Ports of Los Angeles and Long Beach (San Pedro Bay Ports) in 2006 passed regulations establishing timelines forcing the retirement of older diesel trucks. Onroad emissions measurements of heavy-duty diesel trucks were collected over a three-year period, beginning in 2008, at a Port of Los Angeles location and an inland weigh station on the Riverside freeway (CA SR91). At the Port location the mean fleet age decreased from 12.7 years in April of 2008 to 2.5 years in May of 2010 with significant reductions in carbon monoxide (30\%), oxides of nitrogen (48\%) and infrared opacity (a measure of particulate matter, 54\%). We
\end{abstract}


also observed a twenty-fold increase in ammonia emissions as a result of new, stoichiometrically combusted, liquefied natural gas powered trucks. These results compare with changes at our inland site where the average ages were 7.9 years in April of 2008 and 8.3 years in April of 2010, with only small reductions in oxides of nitrogen (10\%) being statistically significant. Both locations have experienced significant increases in nitrogen dioxide emissions from new trucks equipped with diesel particle filters; raising the mean nitrogen dioxide to oxides of nitrogen ratios from less than $10 \%$ to more than $30 \%$ at the Riverside freeway location.

\section{INTRODUCTION}

Since 1998 when the State of California declared diesel particulate matter (DPM) a toxic air contaminant, a number of California and Federal regulations to reduce DPM have been put into law with notable reductions (1-4). Despite the progress, growth in diesel vehicle activity has outpaced the reductions to where they are now estimated by official government inventories to be the dominant mobile source for both oxides of nitrogen $\left(\mathrm{NO}_{\mathrm{x}}\right)$ and fine particulate matter (PM) (5). This has led to additional Federal regulations beginning with 2007 model year diesel engines which further reduces the national DPM limit to $0.01 \mathrm{~g} / \mathrm{bhp}-\mathrm{hr}$ in concert with a transition to a $0.2 \mathrm{~g} / \mathrm{bhp}-\mathrm{hr}$ standard for $\mathrm{NO}_{\mathrm{x}}$ emissions after 2010 (6-8). The large reductions mandated by these standards, an order of magnitude reduction in the case of DPM, will likely require manufacturers to introduce new aftertreatment devices such as diesel particle filters (DPF) and selective catalytic reduction (SCR) systems. Since the service life of a heavy-duty diesel vehicle (HDDV) can be lengthy, delaying the benefits of the new standards, the state of California and some local California agencies have enacted additional requirements to speed up the fleet penetration of these lower emitting trucks by forcing the retirement of pre-2007 HDDVs. 
In the life cycle of a HDDV the shuttling of freight over short distances has traditionally been their last job before the scrap yard. The Ports of Los Angeles and Long Beach, California were no exception with a HDDV fleet that in 2005 averaged 12.7 years of age and were estimated to be responsible for approximately $9.5 \%$ and $6.25 \%$ of the $\mathrm{PM}$ and $\mathrm{NO}_{\mathrm{x}}$ produced in the entire South Coast Air Basin $(9,10)$. Combined, these two ports are the largest in the US and the sixth busiest in the world and in 2006 they approved the San Pedro Bay Ports Clean Air Action Plan (CAAP) $(11,12)$. The CAAP addressed all of the various port related air pollution sources with specific reduction goals for $\mathrm{PM}, \mathrm{NO}_{\mathrm{x}}$, and sulfur oxides (13). This paper will specifically examine the emission changes in the on-road HDDV fleet as the forced retirement mandate of the CAAP is implemented at the Ports of Los Angeles and Long Beach.

Since the Port authority controls access to all of the berths, the CAAP specified a timeline by which only newer, and lower-emitting HDDVs operated by approved concessionaires would be allowed access. This changed the business model at the Port from largely a collection of independent owner-operators to registered concessionaires who are responsible for vehicle maintenance, insurance, security, and safety measures. In addition the CAAP set a 50\% government grant funding goal to encourage the purchase of new vehicles that are powered by alternatives to diesel fuel (13).

The CAAP mirrors many of the statewide California replacement requirements but on an accelerated time schedule. Beginning on October 1, 2008 all class 8 trucks (GVWR 33,001 lbs and greater) with pre-1989 engines were banned from entering the Port. This was followed by a January 1, 2010 ban for class 8 trucks with engines manufactured before 1994, and any remaining 1994 to 2003 class 8 trucks had to be retrofitted with aftertreatment devices to meet an 85\% reduction in PM emissions and a 25\% $\mathrm{NO}_{\mathrm{x}}$ reduction standard. Finally on January 1, 2012 
all class 8 trucks that do not meet the 2007 Federal emission standards will be banned from the Port (13).

To help in the rapid fleet turnover a fee program was instituted that charges the concessionaires, and any infrequent (less than 24 moves per year) or out-of-state operators, according to a specific schedule for each loaded container they move (14). The proceeds of this fee are then routed back in major subsidies for concessionaires to purchase new trucks that meet the 2007 Federal emission standards. Concessionaires had to meet a number of requirements to receive the subsidies including proof that the truck being replaced has been in use at the Port for the past two years, and that the truck would be turned in to the Port to be scrapped (15). Grants totaling \$67 million have been approved for the purchase of diesel and liquefied natural gas (LNG) trucks, and it is estimated that an additional \$600 million in private investment has been contributed towards the purchase of more than 6600 trucks as of August 2010 (16).

Previous research on light-duty vehicle emissions where measurements were repeatedly collected from the same location during the same time of the year have proved effective for documenting fleet emission trends (17). Using a similar approach this paper reports on a series of three campaigns made since 2008 at two locations in the South Coast Air Basin of Southern California to investigate HDDV emissions trends and in specific results of the truck retirement program at the Ports of Los Angeles and Long Beach.

\section{EXPERIMENTAL SECTION}

Located within the South Coast Air Basin of California the two emissions measurement sites were chosen to yield complementary, but not identical, fleet emissions data to compare and to contrast any emission differences as a result of fleet changes. At the Port of Los Angeles the measurements were conducted on lane \#1 at the Water St. exit gate for TRAPAC Inc. container 
operations (berths 135-139) near the intersection of Fries Ave. and Water Street in Wilmington, CA. The trucks were measured as they accelerated away from the exit checkpoint ( $0^{\circ}$ grade $)$ in a low speed, high load operating mode. The inland site was the Peralta weigh station, operated by the California Highway Patrol, located on the eastbound side of the Riverside Freeway (California State Route 91) just west of exit 39 (Weir Canyon Rd.). The trucks’ emissions were sampled after the scales in a single lane while they were accelerating up a slight incline $\left(1.8^{\circ}\right.$ grade) regaining speed to reenter the freeway. We had previously collected emissions data from this location in 1997 (18).

A University of Denver-developed remote vehicle exhaust sensor, named Fuel Efficiency Automobile Test (FEAT), which has been extensively described in the literature, collected the HDDV emission measurements for this study (19-21). The instrument has a light source and four non-dispersive infrared (NDIR) detectors capable of monitoring carbon monoxide (CO), carbon dioxide $\left(\mathrm{CO}_{2}\right)$, and hydrocarbons (HC), which are paired with two dispersive ultraviolet (UV) spectrometers that measure nitric oxide (NO), sulfur dioxide $\left(\mathrm{SO}_{2}\right)$, ammonia $\left(\mathrm{NH}_{3}\right)$, and nitrogen dioxide $\left(\mathrm{NO}_{2}\right)$. The dual element light source is composed of a silicon carbide gas drier igniter which supplies the infrared wavelengths while a xenon arc lamp provides the necessary UV wavelengths. The sensor measures only vehicle exhaust gases as a ratio to exhaust $\mathrm{CO}_{2}$ because the path length of the plume is unknown. These molar ratios can be converted into fuelspecific emissions of grams of pollutant per kilogram of fuel burned by carbon balance using the molecular weight of each species and the fuels' carbon mass fraction, after adjusting the $\mathrm{HC} / \mathrm{CO}_{2}$ ratio to account for the poor quantification of certain hydrocarbon species by NDIR absorption $(22,23)$. By scaling the $\mathrm{HC} / \mathrm{CO}_{2}$ ratio as reported by Singer et al., the fuel specific $\mathrm{HC}$ emissions reported by the FEAT are comparable to a measurement reported with a flame ionization 
detector (22). For diesel fuel we used a scaling factor of 2 and a carbon mass fraction of 0.86 and for natural gas we used a scaling factor of 3.13 and a carbon mass fraction of 0.75 . IR \%opacity readings report the reduction of IR signal caused by exhaust soot particles, as measured at the IR reference wavelength $(3.9 \mu \mathrm{m})$, correlated to exhaust $\mathrm{CO}_{2}$. Reductions in fleet average IR \%opacity are proportional to reductions in the fuel based soot mass and number emissions only to the extent that the observed diesel soot has the same size distribution and optical properties over the measurement period. The proportionality constant is not well known but the data suggests an IR \%opacity of $0.5 \%$ corresponds to between 0.5 and 2 grams of soot $/ \mathrm{kg}$ of fuel.

Quality assurance calibrations were performed in the field at least twice daily and at other times as dictated by the atmospheric conditions using three certified gas mixtures (Scott Specialty Gases, Longmont, $\mathrm{CO}$ ) containing $6 \% \mathrm{CO}, 0.6 \%$ propane, $6 \% \mathrm{CO}_{2}, 0.3 \% \mathrm{NO}$ and $0.04 \% \mathrm{SO}_{2}$ in nitrogen; $0.05 \% \mathrm{NO}_{2}$ and $15 \% \mathrm{CO}_{2}$ in air; $0.1 \% \mathrm{NH}_{3}$ and $0.6 \%$ propane in nitrogen. We used dedicated copper tubing that had been passivated with the specific gas mixture from each calibration cylinder for all of the current measurements. These calibrations account for day-to-day variations in instrument sensitivity and variations in ambient $\mathrm{CO}_{2}$ levels caused by atmospheric pressure and instrument path length.

The majority of HDDVs in the US have elevated exhaust stacks that require the remote sensing beam to be $4-4.5 \mathrm{~m}$ above the ground for sampling. This elevation was accomplished with the use of two guy wire stabilized scaffolding towers on each side of the roadway that raised the source and detectors to the exhaust sampling height (18). Attached to the scaffolding were a pair of parallel infrared beams (Maxi-beam, Banner Industries) 1.83 meters apart, located about 1.8 meters above the roadway to measure the speed and acceleration of the trucks. A third infrared beam mounted on a tripod was used for detecting the front of the truck and triggering 
the 1 s emission measurement. Figure 1 is a photograph showing the setup at the Peralta weigh station site. The locations of the scaffolding and measurement beams were carefully marked to insure that the sampling was conducted at the same location each year. A freeze-frame video image of the front of each truck was recorded along with the emission measurements and the license plate number was used to retrieve non-personal vehicle data from the state registration records of Arizona, California, Illinois, Indiana (only in 2009), Oklahoma, Texas (only in 2010) and Washington (only in 2010).

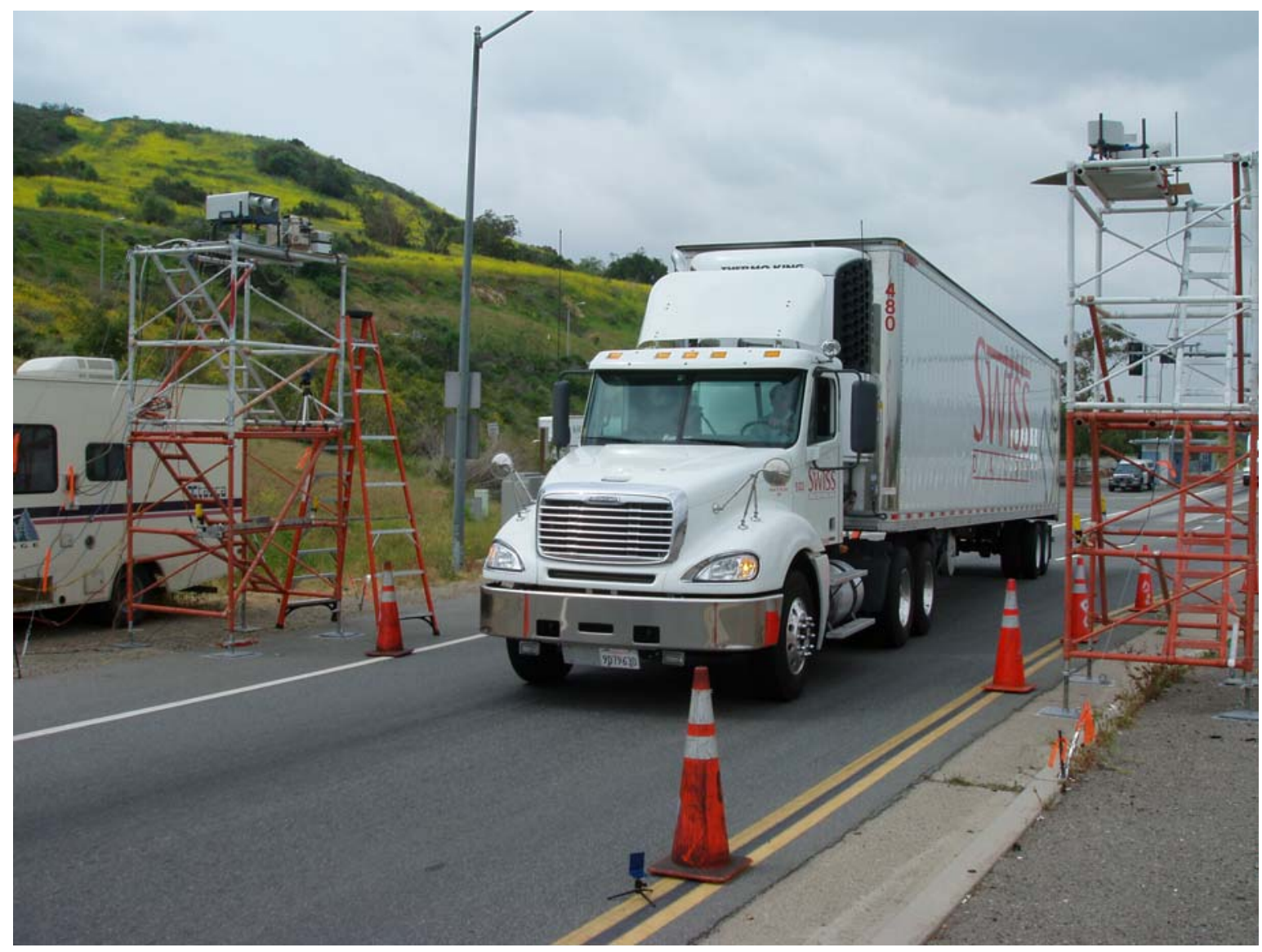

Figure 1. Photograph of the emissions sampling setup at the Peralta weigh station site. Shown on top of the scaffolding are a commercial remote sensing unit (on the left) and the University of Denver's FEAT multi-species remote sensor (on the right). The speed sensing units are mounted in the middle of the orange scaffolding section. The data acquisition computers and calibration cylinders are contained in the motorhome at the left. 
US emission regulations for HDDVs are enforced against the engine model year. This information can be obtained only from the emissions certification sticker on each vehicle's engine. The information that is available from the state registration data provides only the chassis model year. When we report a vehicle model year it is a chassis model year though we often find that a HDDV engine is one year older than the chassis. The age results in this manuscript are obtained by subtracting the average chassis model year from the date of the measurement.

We carried out five days of emissions measurements at each of the sampling sites for three consecutive years (2008 - 2010). The exact dates of the measurements changed slightly from year to year as dictated by the schedule that the California Highway Patrol operated the Peralta weigh station. The emission measurements and vehicle registration information for each site were assembled into a final database for each year that will be available for download from our website at www.feat.biochem.du.edu.

\section{RESULTS AND DISCUSSION}

Table 1 lists the sampling dates, number of trucks, mean chassis model year, emissions with standard errors of the mean calculated from the daily means, and mean speed and acceleration. $\mathrm{NO}_{\mathrm{x}}$ emissions have been calculated by converting the measured $\mathrm{gNO} / \mathrm{kg}$ into $\mathrm{gNO}_{2} / \mathrm{kg}$ and summing with the measured $\mathrm{gNO}_{2} / \mathrm{kg}$ emissions. The historical measurements collected in 1997 are less comprehensive than the current data sets with no model year information or speeds determined; the remote sensor used was our first generation non-dispersive UV detector which did not measure $\mathrm{NO}_{2}$ (18). Figure 2 shows the year-over-year trends for NO, $\mathrm{NO}_{2}, \mathrm{NO}_{\mathrm{x}}$ and IR \%opacity for the two locations.

The differences in the base year (2008) $\mathrm{NO}_{\mathrm{x}}$ emission measurements between the two locations are likely the result of a higher load driving mode observed at the Port. At the Port the 
Table 1. Summary of measurement dates, vehicle information, fuel specific emissions and standard errors of the mean.

\begin{tabular}{|c|c|c|c|c|c|c|c|c|}
\hline $\begin{array}{l}\text { Location } \\
\text { Date }\end{array}$ & $\begin{array}{l}\text { Trucks } \\
\text { (Mean MY) }\end{array}$ & $\mathrm{gCO} / \mathrm{kg}$ & $\mathrm{gHC}^{\mathrm{a}} / \mathrm{kg}$ & $\mathrm{gNO}^{\mathrm{b}} / \mathrm{kg} / \mathrm{gNO}_{2} / \mathrm{kg} / \mathrm{gNO}_{\mathrm{x}}^{\mathrm{c}} / \mathrm{kg}$ & $\mathrm{gNH}_{3} / \mathrm{kg}$ & $\mathrm{gSO}_{2} / \mathrm{kg}$ & $\begin{array}{l}\text { IR } \\
\text { \%Opacity }\end{array}$ & $\begin{array}{l}\text { Speed }^{\mathrm{d}} \\
\text { Acceleration }^{\mathrm{e}}\end{array}$ \\
\hline $\begin{array}{l}\text { Port of LA } 2008 \\
\text { April 12, 14-17 }\end{array}$ & $\begin{array}{l}1436 \\
(1995.6)\end{array}$ & $12.7 \pm 0.2$ & $5.3 \pm 0.5$ & $27.1 \pm 0.6 / 3.9 \pm 0.4 / 45.4 \pm 1.2$ & $0.02 \pm 0.01$ & $0.2 \pm 0.1$ & $0.71 \pm 0.1$ & N.A. \\
\hline $\begin{array}{l}\text { Port of LA } 2009 \\
\text { May 4-8 }\end{array}$ & $\begin{array}{l}1912 \\
(2003.5)\end{array}$ & $7.7 \pm 0.7$ & $5.1 \pm 0.4$ & $17.7 \pm 0.6 / 3.3 \pm 0.2 / 30.5 \pm 1.0$ & $0.2 \pm 0.05$ & $-0.02 \pm 0.05$ & $0.44 \pm 0.02$ & $\begin{array}{l}7.5 \pm 0.2 \\
0.8 \pm 0.05\end{array}$ \\
\hline $\begin{array}{l}\text { Port of LA } 2010 \\
\text { May 3-7 }\end{array}$ & $\begin{array}{l}1984 \\
(2007.9)\end{array}$ & $9.2 \pm 0.7$ & $4.8 \pm 0.4$ & $13.6 \pm 0.2 / 2.5 \pm 0.5 / 23.4 \pm 0.4$ & $0.4 \pm 0.1$ & $-0.2 \pm 0.02$ & $0.33 \pm 0.03$ & $\begin{array}{l}8.0 \pm 0.2 \\
0.9 \pm 0.05\end{array}$ \\
\hline $\begin{array}{l}\text { Peralta } 1997 \\
\text { Aug. 25-29 }\end{array}$ & $\begin{array}{l}3918 \\
\text { N.A. }\end{array}$ & $16.1 \pm 0.7$ & $5.0 \pm 0.4$ & 19.2 \pm 0.4 / N.A. / N.A. & N.A. & N.A. & $2.5 \pm 0.1$ & N.A. \\
\hline $\begin{array}{l}\text { Peralta } 2008 \\
\text { April 4, 7-10 }\end{array}$ & $\begin{array}{l}2629 \\
(2000.4)\end{array}$ & $10.0 \pm 0.4$ & $2.7 \pm 0.2$ & $16.4 \pm 0.2 / 2.1 \pm 0.2 / 27.3 \pm 0.3$ & $0.03 \pm 0.02$ & $0.3 \pm 0.1$ & $0.73 \pm 0.01$ & $\begin{array}{l}21.6 \pm 0.1 \\
1.8 \pm 0.1\end{array}$ \\
\hline $\begin{array}{l}\text { Peralta } 2009 \\
\text { April 27-May } 1\end{array}$ & $\begin{array}{l}2142 \\
(2001.3)\end{array}$ & $10.6 \pm 0.5$ & $4.8 \pm 0.2$ & $15.3 \pm 0.4 / 1.9 \pm 0.2$ / $25.4 \pm 0.5$ & $0.03 \pm 0.02$ & $0.2 \pm 0.1$ & $0.73 \pm 0.03$ & $\begin{array}{l}21.7 \pm 0.2 \\
1.4 \pm 0.07\end{array}$ \\
\hline $\begin{array}{l}\text { Peralta } 2010 \\
\text { April 26-30 }\end{array}$ & $\begin{array}{l}1871 \\
(2002)\end{array}$ & $10.0 \pm 0.5$ & $4.2 \pm 0.2$ & $14.7 \pm 0.4 / 1.9 \pm 0.04 / 24.5 \pm 0.7$ & $0.01 \pm 0.01$ & $-0.2 \pm 0.01$ & $0.68 \pm 0.05$ & $\begin{array}{l}21.5 \pm 0.3 \\
1.2 \pm 0.2\end{array}$ \\
\hline
\end{tabular}

a grams of HC using the FID adjustments noted in the text.

${ }^{\mathrm{b}}$ grams of NO

c grams of $\mathrm{NO}_{2}$

${ }^{\mathrm{d}}$ kilometers per hour

e kilometers per hour / sec 


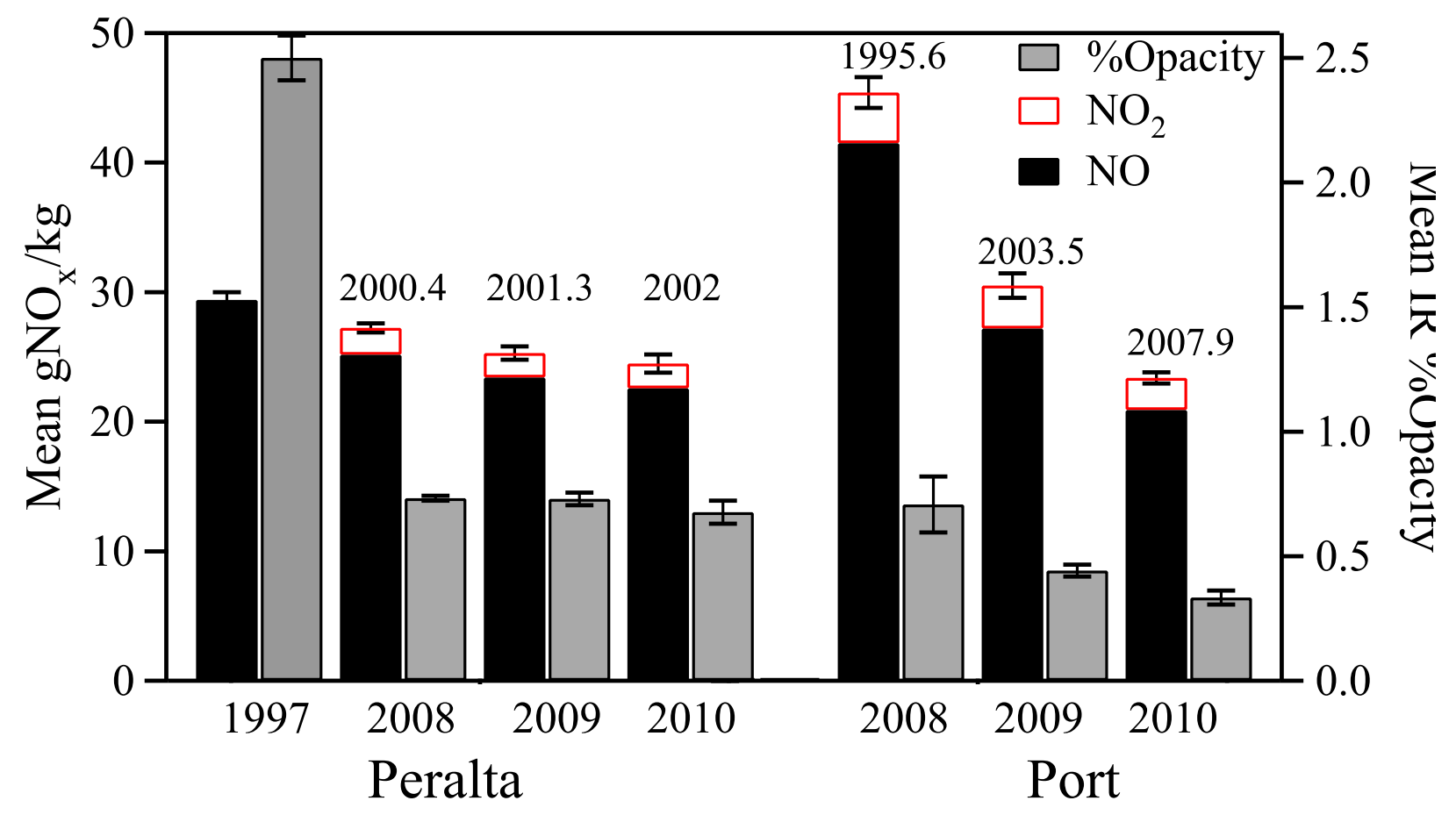

Figure 2. Mean gNO/kg, gNO $2 / \mathrm{kg}, \mathrm{gNO}_{\mathrm{x}} / \mathrm{kg}$ and IR \%Opacity versus measurement year for the two sampling locations. All of the nitrogen species are plotted as grams of $\mathrm{NO}_{2}$. The error bars reported are for total $\mathrm{NO}_{\mathrm{x}}$ and the standard errors of the mean were calculated from the daily means. Above each pair of measurement bars is the mean chassis model year of the measured fleet.

trucks are accelerating away from the last checkpoint after a complete stop (see Table 1 for operating differences). For the 2008 measurement year the mean $\mathrm{NO}_{\mathrm{x}}$ emissions at the Port are $66 \%$ higher. Some of that difference can be attributed to the older age of the Ports fleet, but even after normalizing the Peralta fleets age to the Port fleet (1995.6 MY) the Port fleet still has 37\% higher $\mathrm{NO}_{\mathrm{x}}$ emissions. When we compare the same trucks measured for all three years at both locations (44 trucks with 60 measurements at Peralta and 88 measurements at the Port, with a mean chassis model year of 2004.3) we also find higher $\mathrm{NO}_{\mathrm{x}}$ emissions at the Port (89\% more) with the difference increasing for the newer model years. These all suggest that there is a driving 
mode penalty at the Port location resulting in higher $\mathrm{NO}_{\mathrm{x}}$ emissions which has to be considered when comparing the two fleets.

The historical comparison at Peralta shows emissions reductions between 1997 and 2010 for all of the species reported, CO (38\%), HC (16\%), NO (24\%) and IR \%opacity (72\%). These trends are similar to those reported in the literature for HDDV CO, HC and PM emissions during the 1990s while $\mathrm{NO}_{\mathrm{x}}$ emissions showed little change during this period $(3,4,24)$. The reductions in NO emissions have likely occurred only recently (since 2004), and NO is the only species measured in 1997 that still continues to shows a statistically significant reduction in the new data.

The regulated turnover of the Ports truck fleet has resulted in a dramatic fleet transformation with the mean age decreasing by 10.2 years between 2008 and 2010. In addition the fleet at our measurement location has gone from being entirely powered by diesel fuel in 2008 to $11 \%$ of the 2010 measurements originating from liquefied natural gas powered trucks. The combinations of past and future bans for older HDDV and new purchasing subsidies have compelled the majority of truck owners to buy new instead of retrofitting older models. In 2010 83\% of the truck measurements were collected from 2008 chassis model year vehicles or newer compared with no measurements in calendar year 2008. In this two year span significant reductions in fleet $\mathrm{CO}(30 \%), \mathrm{NO}_{\mathrm{x}}(48 \%)$ and IR \%opacity (54\%) have occurred. When just HDDV are compared the observed reductions for CO (61\%) and HC (17\%) are significantly higher as the natural gas vehicles are a new and significant source for both species. The $\mathrm{NO}_{\mathrm{x}}$ and IR \%opacity reductions are very similar to reported $\mathrm{NO}_{\mathrm{x}}$ and black carbon reductions seen for a similar retirement and retrofit program at the Port of Oakland (25). For comparison, the HDDV fleet at the Peralta weigh station has seen an increase in the mean chassis age by 0.4 years with 
only a small decrease in $\mathrm{NO}_{\mathrm{x}}(10 \%)$ and no statistically significant changes in the other species. At Peralta, 2008 and newer chassis model year vehicles made up only 14\% of all measurements in 2010 a significant increase from 3\% in 2008 but small compared to the port location.

The $\mathrm{NO}_{\mathrm{x}}$ Federal emission standards for HDDV have been reduced approximately $75 \%$ (5g/ghp-hr in 1995 to 1.2g/bhp-hr in 2007) while the PM reductions of 90\% are likely larger as the performance of DPF equipped HDDV have exceeded expectations (26). Our observed reductions in $\mathrm{NO}_{\mathrm{x}}$ and IR \%opacity at the Port location are less than a direct extrapolation of the regulations reductions and several factors likely contribute to these differences. Historically $\mathrm{NO}_{\mathrm{x}}$ in-use emissions measurements have proven to show smaller reductions than one would predict from the regulations and that is likely the case here as our observed $\mathrm{NO}_{\mathrm{x}}$ reductions are similar to other in-use measurements from the Port of Oakland $(24,25)$. Our IR \%opacity method likely underestimates the true PM reductions at the Port location, though we believe correctly reports a significant improvement. Several difficulties for this technique are its limits in defining the Port's baseline (2008) smoke levels as trucks with truly opaque plumes are difficult to measure at such low light levels and a potential zero offset that will automatically reduce the measured benefit.

The reductions in the $\mathrm{NO}_{\mathrm{x}}$ and opacity emissions at the Port can best be illustrated by showing the changes in the emissions distributions over the last two years. Figure 3 is a plot of fleet fraction versus binned $\mathrm{gNO}_{\mathrm{x}} / \mathrm{kg}$ for the two locations for measurement year 2008 (top panel) and year 2010 (bottom panel). Careful examination of the 5, 10 and 15 gNO $_{\mathrm{x}} / \mathrm{kg}$ bins shows that the HDDV emissions at Peralta have moved to lower levels during the two years as a result of fleet turnover, though these shifts are small compared to the changes at the Port. The fact that the final emissions distributions look similar at the two sites, despite the large reductions 

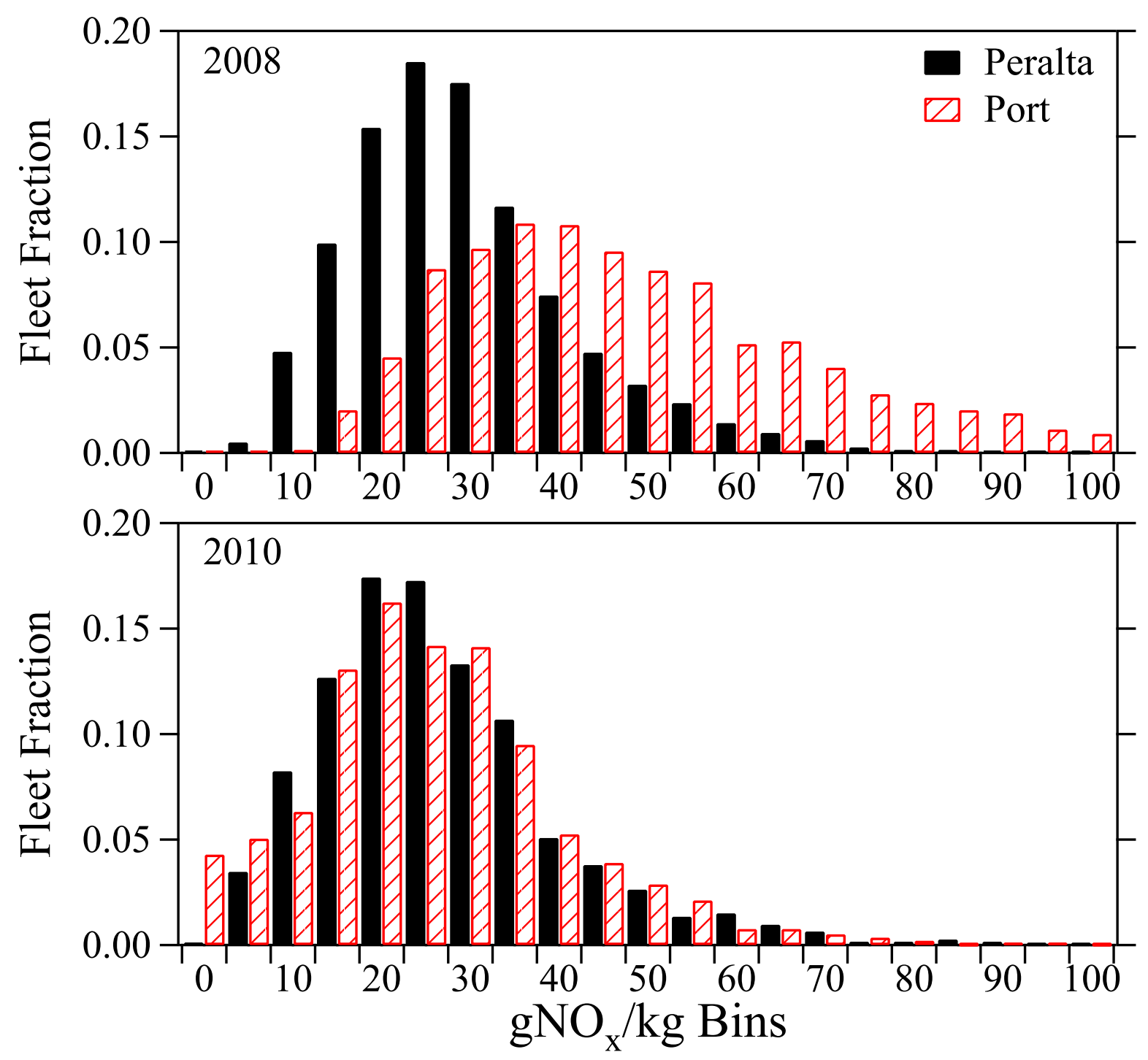

Figure 3. Fleet fraction versus binned gNOx/kg emissions for the Peralta weigh station (solid bars) and the Port location (hatched bars) for the 2008 (top panel) and 2010 (bottom panel) measurement year.

observed at the Port, is a consequence of the Ports higher $\mathrm{NO}_{\mathrm{x}}$ driving mode as previously discussed. Figure 4 is a similar plot but for just the Port data, where fleet fraction is plotted versus binned IR \%Opacity for the 2008 and 2010 measurement years. The fraction of trucks in the lowest two bins has nearly doubled with the majority of the high emitters being completely eliminated. 


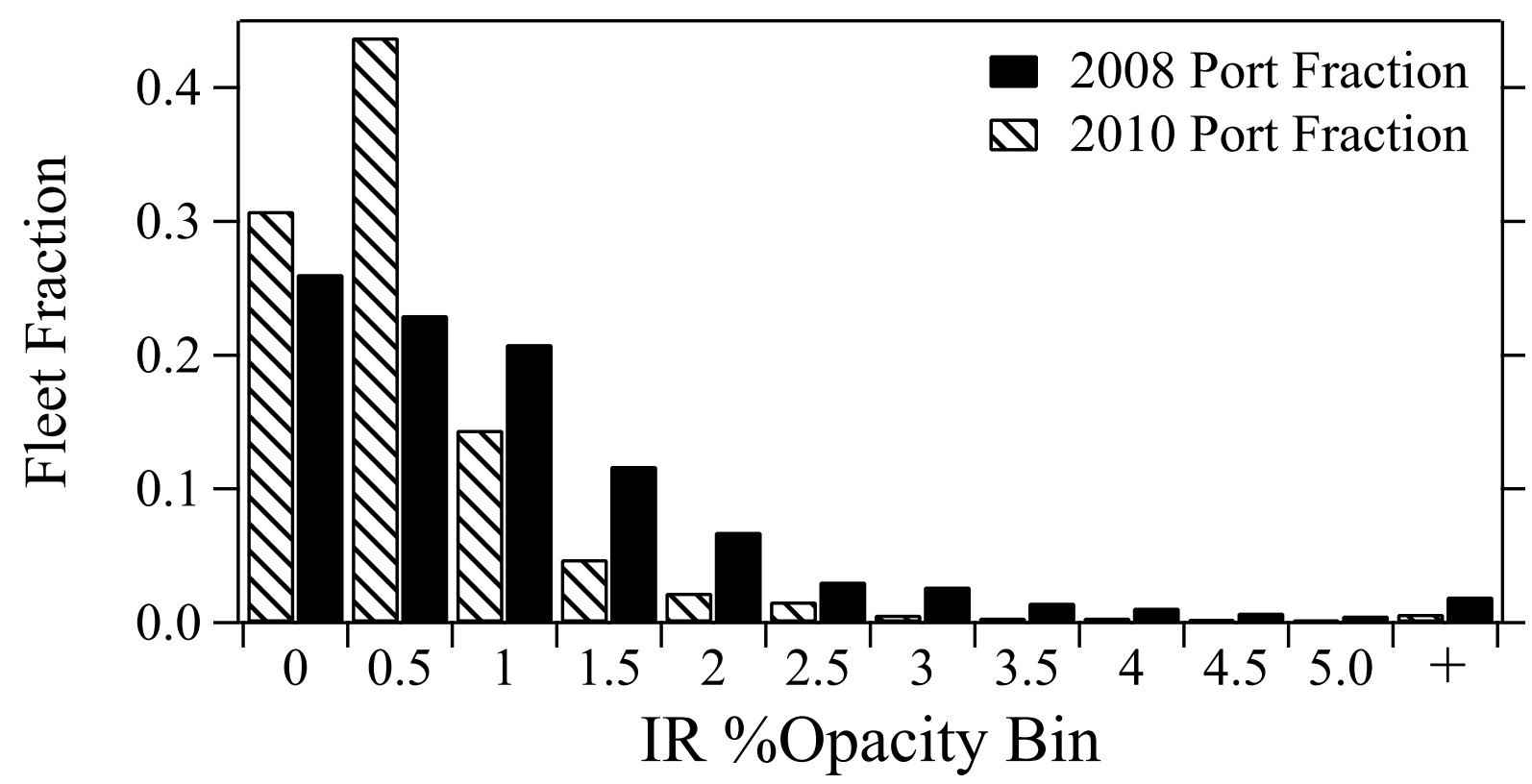

Figure 4. Port of Los Angeles site fleet fraction versus binned IR \%Opacity for the 2008 (solid bars) and 2010 (hatched bars) measurements.

Previous emission trend studies of light-duty vehicles have shown that mean fleet model years generally track the elapsed time between the yearly measurements leaving the fleet age unchanged (17). At Peralta the average age increased 0.1 model years in 2009 and an additional 0.3 model years in 2010. The older observed fleet was likely a combination of the economic downturn and previous truck purchasing decisions. Diesel fuel sales in the State of California peaked in 2007 and dropped 8.3\% in 2008 and an additional 8.7\% in 2009 reflecting fewer HDDV on the road and likely translating to lower demand for new trucks (27). It is also apparent from our observed model year distributions that many companies moved up their purchasing decisions and purchased 2007 model year trucks (with pre-DPF equipped 2006 engines). The 2010 measured chassis model year fractions for Peralta showed that 2007 chassis model year trucks made up $12.7 \%$ of the fleet, by far the largest (2000 models were the next largest with 8.7\%) model year fraction. The combination of pre-purchases and the economic slowdown have 
resulted in a noticeable lag in the introduction of lower emitting trucks to the general California truck fleet and likely the entire country.

Figure 5 is a combined plot of the $\mathrm{NO}_{2} / \mathrm{NO}_{\mathrm{x}}$ mass ratios and standard errors of the mean for the three data sets from Peralta (open symbols) and the last two years data for the Port of LA (filled symbols). Many DPF regeneration strategies rely on the catalyzed creation of $\mathrm{NO}_{2}$ upstream of the particle filter for oxidation of trapped soot particles. Beginning with the 2008 chassis model year the $\mathrm{NO}_{2} / \mathrm{NO}_{\mathrm{x}}$ ratio increases significantly at both locations with the youngest vehicles for each model year having the highest ratios and then decreasing with filter age. At both locations, these increased ratios are a combined result of decreasing $\mathrm{NO}_{\mathrm{x}}$ emissions with large increases (more than double at Peralta) in $\mathrm{NO}_{2}$ emissions. The larger $\mathrm{NO}_{2} / \mathrm{NO}_{\mathrm{x}}$ ratios measured at Peralta may be a result of higher exhaust temperatures as $\mathrm{NO}_{2}$ formation in a DPF is temperature dependent (26). Because the Port has strict idling laws, drivers often turn off their engines while stopped at the exit station prior to our measurement location, unlike at Peralta where the trucks are constantly moving. Changes to the ambient $\mathrm{NO}_{2} / \mathrm{NO}_{\mathrm{x}}$ ratio in the South Coast Air basin are of great interest as increases in this ratio have been estimated to increase local ozone formation (28). While some assume that 2010 compliant engines with SCR technologies will eliminate the excess $\mathrm{NO}_{2}$ emissions, their on-road operation appears to be subject to certain temperature and other operating requirements $(29,30)$. It therefore remains to be seen how these systems will cycle in real use and what the $\mathrm{NO}_{2} / \mathrm{NO}_{\mathrm{x}}$ ratio will be during periods when the SCR is not operational.

The changes at the Port have not been without some unintended consequences. As part of the CAAP an effort was made to encourage the use of alternatives to diesel fuel with an increased subsidy (up to $\$ 100,000.00$ which is double the subsidy for a new HDDV) for the 


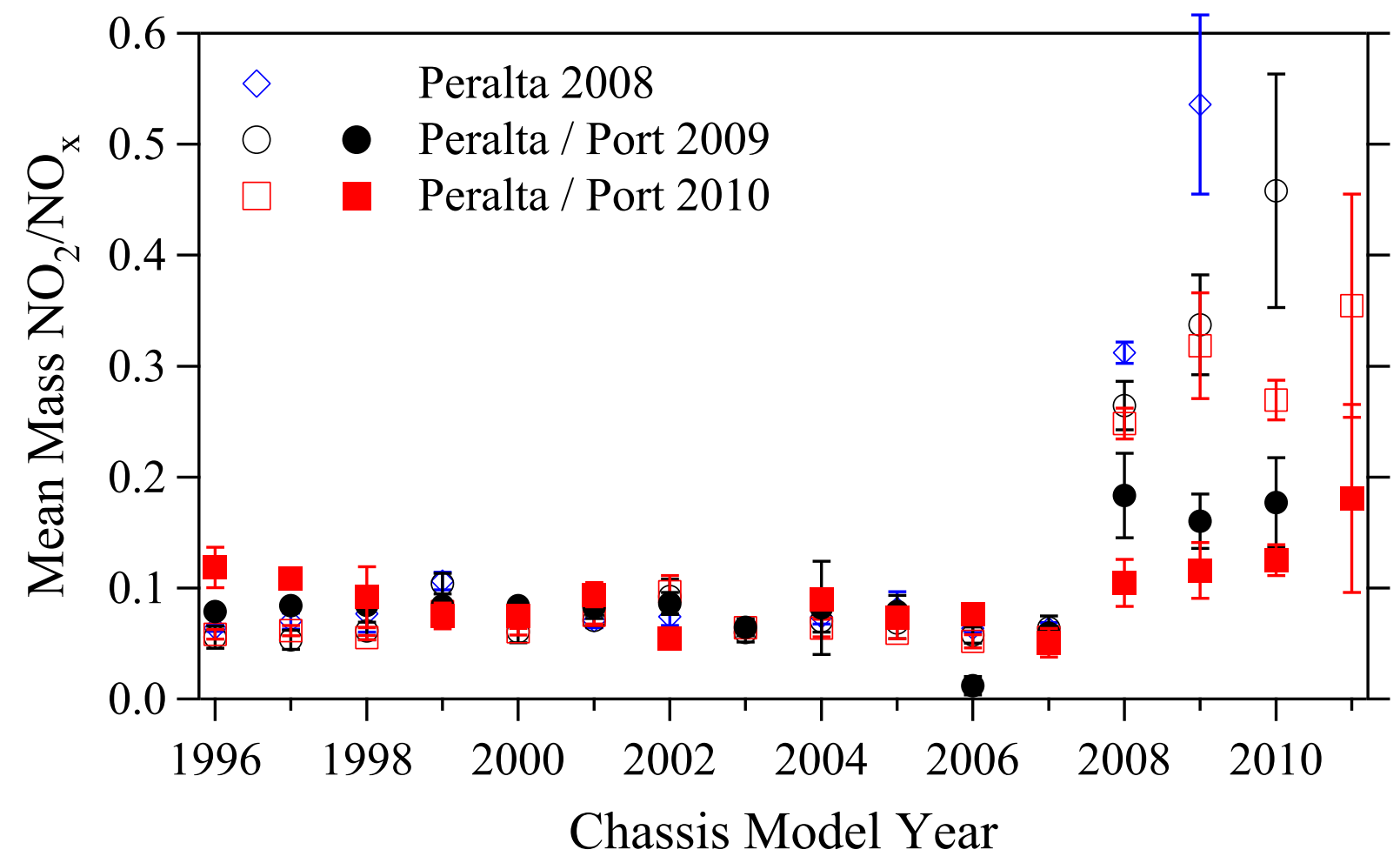

Figure 5. Mean $\mathrm{NO}_{2} / \mathrm{NO}_{\mathrm{x}}$ mass ratios versus chassis model year for the three measurement years at the Peralta weigh station (open symbols) and two measurement years for the Port of LA (filled symbols). The 2008 data from the Port of LA are not included due to the lack of 2008 or newer vehicles. The standard error of the mean is plotted for each data set and is calculated from the daily emission means.

purchase of alternative fueled vehicles (15). Currently that has resulted in a small population (about $6 \%$ of the fleet) of two types of LNG powered trucks. One type is spark ignited and the gas is combusted stoichiometrically, with a 3-way catalytic converter as part of its emissions control equipment and ground level exhaust (31). The other is a dual fuel truck that compression ignites the gas in a 2004 certified lean burn engine using a small injection of diesel fuel to ignite the mixture (32). Figure 6 is a graph that compares the mean $\mathrm{gNO}_{\mathrm{x}} / \mathrm{kg}, \mathrm{gNH}_{3} / \mathrm{kg}$ and opacity emissions of both types of LNG trucks against HDDV for the two measurement years that they have been in operation. The oldest HDDV, the 2007 and older models have the highest opacity measurements showing that both the DPF equipped HDDV (2008 and newer HDDV) and the 


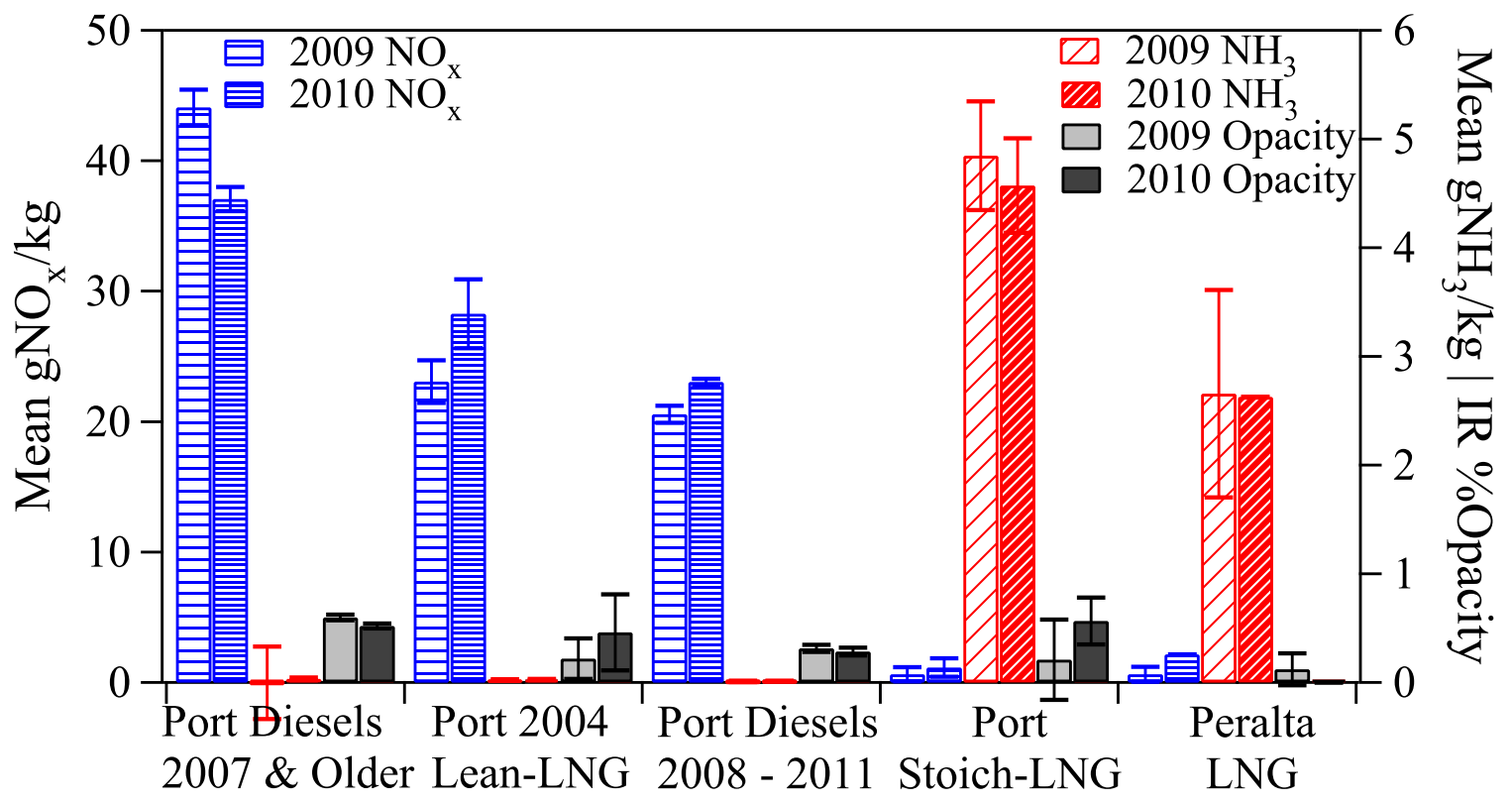

Figure 6. Emissions comparison of diesel and liquefied natural gas (LNG) trucks at the Port location. Data from 2009 and 2010 measurement years are plotted for $\mathrm{gNO}_{\mathrm{x}} / \mathrm{kg}$ (horizontal hatched bars left axis), $\mathrm{gNH}_{3} / \mathrm{kg}$ (diagonally hatched bars right axis) and IR \%Opacity (solid bars right axis). The errors shown are standard errors of the mean calculated from the daily means for the chassis model year 2007 and older Port diesels (871 and 313 measurements), the 2008 - 2011 Port diesels (930 and 1472 measurements) and the stoichiometric LNG fleet (78 and 172 measurements). The standard errors of the mean are calculated from the individual measurements for the lean burn LNG fleet (22 and 23 measurements) and the Peralta measurements (5 stoichiometric LNG trucks in 2009 and 1 stoichiometric and 1 lean burn LNG truck in 2010).

LNG trucks have reduced particle emissions with most of the LNG group emission means being indistinguishable from zero. The $\mathrm{gNO}_{\mathrm{x}} / \mathrm{kg}$ emissions for the LNG lean burn engine are between the older and newer diesel trucks in line with this engines certification standard suggesting that engine design standards and not the fuel used is a more important factor for reducing $\mathrm{NO}_{\mathrm{x}}$ emissions. The stoichiometric LNG trucks measured in this study have very large $\mathrm{NH}_{3}$ emissions along with elevated $\mathrm{CO}$ (54 versus $4 \mathrm{gCO} / \mathrm{kg}$ ) and methane emissions (8.6 versus 3.4 gHC/kg which negates some of LNG's greenhouse gas benefit) compared with the newest (2008 and 
newer) HDDV. From a purely emissions comparison standpoint the extra expense for a LNG trucks versus a DPF equipped diesel does not appear to be justified.

Vehicle $\mathrm{NH}_{3}$ emissions result from reduction of $\mathrm{NO}_{\mathrm{x}}$ in the presence of a reducing catalysis and available hydrogen (often the limiting reagent) and have long been known to occur in the light-duty gasoline fleet $(33,34)$. The $\mathrm{gNH}_{3} / \mathrm{kg}$ levels observed at the Port location for the catalytically equipped, stoichiometrically operating LNG trucks measured in this study are eight to nine times those reported for current light-duty California fleets and due to the reactive nature of $\mathrm{NH}_{3}$ likely offset some of the benefits of low primary particle emissions $(35,36)$. Corroboration of the Port measurements was found in five refuse trucks operating at our Peralta location in 2009. The refuse trucks used the same LNG engine as the Port trucks, but with an elevated exhaust stack that provided more concentrated plumes to measure. While the $\mathrm{NH}_{3}$ emissions were lower at Peralta, likely owing to the lower load as previously discussed, these values are still almost five times those of the light-duty fleet.

As these trucks' catalysts age, one would expect the reduction capabilities to decrease, increasing $\mathrm{NO}_{\mathrm{x}}$ emissions and decreasing ammonia. The 2010 data qualitatively show this with an increase in $\mathrm{NO}_{\mathrm{x}}$ accompanied by a decrease in $\mathrm{NH}_{3}$ but after only one year, these differences are not statistically significant. As there currently are no Federal or California regulations that limit $\mathrm{NH}_{3}$ emissions from motor vehicles, this currently is a benefit to the manufacturers allowing these engines to meet the most stringent $2010 \mathrm{NO}_{\mathrm{x}}$ emissions limit without additional aftertreatment.

A second unintended consequence involved the January 1, 2010 Port deadline that left truck owners with the apparent choices to upgrade to new vehicles, retrofit older trucks with 1994 to 2003 model year engines gaining two additional years of service life or move operations. 
Most appear to have chosen replacement; however we are aware of three vehicles registered in California in 2008 that showed up in measurements made at the Port of Houston in July of 2009 now registered in Texas. Table 2 provides the age normalized (to the 2008 measurements model year distribution) mean emission measurements for chassis model year 1995 to 2004 vehicles at our two measurement locations. At the Port location, close to $90 \%$ of these vehicles no longer show up at our measurement site, while the remaining vehicles have emissions that do not meet the targeted retrofit reductions. The opacity measurements show significant reductions ( 29\%) but they are less than half of those observed for the 2008 and newer trucks which the retrofits are designed to be comparable to. In addition the Port trucks show increases in both $\mathrm{NO}_{2}$ and total $\mathrm{NO}_{\mathrm{x}}$ emissions, not reductions as mandated in the CAAP (28).

Table 2. Age-normalized 1995 to 2004 chassis model year mean emissions and standard errors of the mean.

\begin{tabular}{|c|c|c|c|c|c|c|}
\hline \multirow[b]{2}{*}{ Year } & \multicolumn{3}{|c|}{ Port of LA } & \multicolumn{3}{|c|}{ Peralta Weigh Station } \\
\hline & $\begin{array}{l}\mathrm{gNO}_{\mathrm{x}}^{\mathrm{b}} / \mathrm{kg} \\
\text { (Counts) }\end{array}$ & $\begin{array}{l}\mathrm{gNO}_{2} / \mathrm{kg} \\
\text { (Counts) }\end{array}$ & $\begin{array}{c}\text { IR } \\
\text { \%Opacity } \\
\text { (Counts) }\end{array}$ & $\begin{array}{l}\mathrm{gNO}_{\mathrm{x}}^{\mathrm{b}} / \mathrm{kg} \\
\text { (Counts) }\end{array}$ & $\begin{array}{l}\mathrm{gNO}_{2} / \mathrm{kg} \\
\text { (Counts) }\end{array}$ & $\begin{array}{c}\text { IR } \\
\text { \%Opacity } \\
\text { (Counts) }\end{array}$ \\
\hline 2008 & $\begin{array}{c}45.0 \pm 1.4 \\
(913)\end{array}$ & $\begin{array}{c}3.9 \pm 0.5 \\
(913)\end{array}$ & $\begin{array}{c}0.63 \pm 0.12 \\
(842)\end{array}$ & $\begin{array}{c}29.3 \pm 0.5 \\
(1537)\end{array}$ & $\begin{array}{c}2.2 \pm 0.2 \\
(1537)\end{array}$ & $\begin{array}{c}0.71 \pm 0.02 \\
(1472)\end{array}$ \\
\hline 2009 & $\begin{array}{c}44.8 \pm 1.6 \\
(660)\end{array}$ & $\begin{array}{c}3.7 \pm 0.3 \\
(660)\end{array}$ & $\begin{array}{c}0.49 \pm 0.03 \\
(622)\end{array}$ & $\begin{array}{c}28.8 \pm 0.7 \\
(1181)\end{array}$ & $\begin{array}{c}2.0 \pm 0.2 \\
(1181)\end{array}$ & $\begin{array}{c}0.69 \pm 0.01 \\
(1117)\end{array}$ \\
\hline $2010^{c}$ & $\begin{array}{c}47.8 \pm 0.6 \\
(117)\end{array}$ & $\begin{array}{c}4.2 \pm 0.3 \\
(117)\end{array}$ & $\begin{array}{c}0.45 \pm 0.06 \\
(108)\end{array}$ & $\begin{array}{c}29.2 \pm 0.8 \\
(901)\end{array}$ & $\begin{array}{c}2.0 \pm 0.1 \\
(901)\end{array}$ & $\begin{array}{c}0.65 \pm 0.05 \\
(844)\end{array}$ \\
\hline $\begin{array}{l}\text { \%Change } \\
2008-2010\end{array}$ & 6.2 & 9.2 & -28.6 & -0.3 & -9.1 & -8.5 \\
\hline
\end{tabular}

${ }^{\mathrm{a}}$ Fleet emissions have been normalized to match the model year distribution for the 2008 measurements at each measurement location.

${ }^{\mathrm{b}}$ grams of $\mathrm{NO}_{2}$.

${ }^{\mathrm{c}}$ Only the HDDV at the Port of LA have been required to install emission retrofit devices. 
In reality very few 1995 to 2004 Port trucks at the Port have installed a California Air Resources Board approved retrofit device. The enforceable regulations specifically only required class 8 trucks to be retrofit (8). Of the 117 measurements in 2010 at the port, 97 of them were from class 7 trucks that are exempt from the retrofit requirements with only 11 measurements coming from compliant class 8 trucks. The class 7 trucks are new to this measurement site with only 2 of the 45 unique trucks having a previous measurement record. While the retrofit rules have been recently extended by the State of California and the Ports to close this loophole, the end result is that a few clever owners were able to gain two additional years of service without the added expense of installing a retrofit device and the Ports missed out on the additional emission benefits (37).

\section{ACKNOWLEDGMENTS}

The authors gratefully acknowledge the financial support from the US Department of Energy Office of Vehicle Technologies (Dr. James J. Eberhardt, Chief Scientist) through the National Renewable Energy Laboratory under NREL subcontract number AEV-8-88609-01 and the South Coast Air Quality Management District under subcontract number 08320. Additionally we acknowledge the assistance of Sgt. Rod Strate, Officers Ron Jordon and Josh Sarinas of the California Highway Patrol and Joseph J. Francis III and Paul Richey of TraPac.

\section{REFERENCES}

1. Part B: Health risk assessment for diesel exhaust. Office of Environmental Health Hazard Assessment; California Environmental Protection Agency: Sacramento, 1998; http://www.arb.ca.gov/regact/diesltac/partb.pdf.

2. $\quad$ Ban-Weiss, G. A.; McLaughlin, J. P.; Harley, R. A.; Lunden, M. M.; Kirchstetter, T. W.; Kean, A. J.; Strawa, A. W.; Stevenson, E. D.; Kendall, G. R., Long-term changes in emissions of 
nitrogen oxides and particulate matter from on-road gasoline and diesel vehicles. Atmos. Environ. 2008, 42, 220-232.

3. Bahadur, R.; Feng, Y.; Russell, L. M.; Ramanathan, V., Impact of California's air pollution laws on black carbon and their implications for direct radiative forcing. Atmos. Environ. 2011, 45, 1162-1167.

4. Kirchstetter, T. W.; Aguiar, J.; Tonse, S.; Fairley, D.; Novakov, T., Black carbon concentrations and diesel vehicle emission factors derived from coefficient of haze measurements in California: 1967-2003. Atmos. Environ. 2008, 42, 480-491.

5. Dallmann, T. R.; Harley, R. A., Evaluation of mobile source emission trends in the United States. J. Geo. Res. 2010, 115, D14305-D14312.

6. Highway diesel progress review. U. S. Environmental Protection Agency; Air and Radiation: EPA420-R-02-016; 2002; www.epa.gov/oms/highwaydiesel/compliance/420r02016.pdf.

7. Regulation to reduce emissions of diesel particulate matter, oxides of nitrogen and other criteria pollutants, from in-use heavy-duty diesel-fueled vehicles. California Code of Regulations; Title 13, Section 2025.

8. In-use on-road diesel-fueled heavy-duty drayage trucks. California Code of Regulations; Title 13, Section 2027.

9. Port of Long Beach air emissions inventory - 2005. Starcrest Consulting Group: Poulsbo, 2007; http://www.polb.com/civica/filebank/blobdload.asp?BlobID=4436.

10. Port of Los Angeles inventory of air emissions 2005. Starcrest Consulting Group: ADP\#050520-525; Poulsbo, 2007; http://www.portoflosangeles.org/DOC/2005_Air_Emissions_Inventory_Full_Doc.pdf.

11. Port of Long Beach, http://www.polb.com/about/facts.asp (accessed Feb. 2011). 
12. Port of Long Beach; Port of Los Angeles, San Pedro Bay Ports Clean Air Action Plan: About the Clean Air Action Plan. http://www.cleanairactionplan.org/about_caap/default.asp (accessed June 2011).

13. 2010 update San Pedro Bay Ports clean air action plan. The Port of Los Angeles; Port of Long Beach: Los Angeles, 2010; http://www.portoflosangeles.org/CAAP/12_21_2010_CAAP_update_full_text.pdf.

14. Port of Los Angeles; Port of Long Beach, Clean truck fee. http://www.polb.com/civica/filebank/blobdload.asp?BlobID=6401 (accessed Feb. 2011).

15. Port of Los Angeles, Grants and funding opportunities. http://www.portoflosangeles.org/ctp/ctp_grants.asp (accessed Feb. 2011).

16. Port of Los Angeles, Port of Los Angeles clean truck program. www.portoflosangeles.org/ctp/CTP_Fact_Sheet.pdf (accessed Feb. 2011).

17. Bishop, G. A.; Stedman, D. H., A decade of on-road emissions measurements. Environ. Sci. Technol. 2008, 42, 1651-1656.

18. Bishop, G. A.; Morris, J. A.; Stedman, D. H.; Cohen, L. H.; Countess, R. J.; Countess, S. J.; Maly, P.; Scherer, S., The effects of altitude on heavy-duty diesel truck on-road emissions. Environ. Sci. Technol. 2001, 35, 1574-1578.

19. Burgard, D. A.; Bishop, G. A.; Stadtmuller, R. S.; Dalton, T. R.; Stedman, D. H., Spectroscopy applied to on-road mobile source emissions. Appl. Spectrosc. 2006, 60, 135A148A.

20. Popp, P. J.; Bishop, G. A.; Stedman, D. H., Development of a high-speed ultraviolet spectrometer for remote sensing of mobile source nitric oxide emissions. J. Air Waste Manage. Assoc. 1999, 49, 1463-1468.

21. Burgard, D. A.; Dalton, T. R.; Bishop, G. A.; Starkey, J. R.; Stedman, D. H., Nitrogen dioxide, sulfur dioxide, and ammonia detector for remote sensing of vehicle emissions. Rev. Sci. Instrum. 2006, 77, 1-4. 
22. Singer, B. C.; Harley, R. A.; Littlejohn, D.; Ho, J.; Vo, T., Scaling of infrared remote sensor hydrocarbon measurements for motor vehicle emission inventory calculations. Environ. Sci. Technol. 1998, 32, 3241-3248.

23. Bishop, G. A., FEAT Math II. http://www.feat.biochem.du.edu/assets/reports/FEAT_Math_II.pdf (accessed June 2011).

24. Yanowitz, J.; McCormick, R. L.; Graboski, M. S., In-use emissions from heavy-duty diesel vehicles. Environ. Sci. Technol. 2000, 34, 729-740.

25. Dallmann, T. R.; Harley, R. A.; Kirchstetter, T., Effects of diesel particle filter retrofits and accelerated fleet turnover on drayage truck emissions at the Port of Oakland. Environ. Sci. Technol. 2011, in press.

26. Herner, J. D.; Hu, S.; Robertson, W. H.; Huai, T.; Collins, J. F.; Dwyer, H.; Ayala, A., Effect of advanced aftertreatment for $\mathrm{PM}$ and $\mathrm{NO}_{\mathrm{x}}$ control on heavy-duty diesel truck emissions. Environ. Sci. Technol. 2009, 43, 5928-5933.

27. California State Board of Equalization, Taxable Diesel Gallons 10 Year Report. http://www.boe.ca.gov/sptaxprog/reports/Diesel_10_Year_Report.pdf (accessed March 2011).

28. Millstein, D. V.; Harley, R. A., Effects of retrofitting emission control systems on in-use heavy diesel vehicles. Environ. Sci. Technol. 2010, 44, 5042-5048.

29. Heeb, N. V.; Zimmerli, Y.; Czerwinski, J.; Schmid, P.; Zennegg, M.; Haag, R.; Seiler, C.; Wichser, A.; Ulrich, A.; Honegger, P.; Zeyer, K.; Emmenegger, L.; Mosimann, T.; Kasper, M.; Mayer, A., Reactive nitrogen compounds (RNCs) in exhaust of advanced $\mathrm{PM}-\mathrm{NO}_{\mathrm{x}}$ abatement technologies for future diesel applications. Atmos. Environ. 2011, 45, 3203-3209.

30. Velders, G. J. M.; Geilenkirchen, G. P.; de Lange, R., Higher than expected $\mathrm{NO}_{\mathrm{x}}$ emission from trucks may affect attainability of $\mathrm{NO}_{2}$ limit values in the Netherlands. Atmos. Environ. 2011, 45, 3025-3033.

31. Cummins Westport Inc., Every alternative. ISL G (North America). http://www.cumminswestport.com/products/islg.php (accessed Feb. 2011). 
32. Westport Power Inc., Westport sells 50 LNG Port trucks to Southern Counties Express; Initial order from leading Port trucker to improve air quality in Los Angeles Basin. http://www.westport.com/media/news-release?story=352 (accessed Feb. 2011).

33. Cadle, S. H.; Mulawa, P. A., Low-molecular-weight aliphatic amines in exhaust from catalyst-equipped cars. Environ. Sci. Technol. 1980, 14, 718-723.

34. Fraser, M. P.; Cass, G. R., Detection of excess ammonia emissions from in-use vehicles and the implications for fine particle control. Environ. Sci. Technol. 1998, 32, 1053-1057.

35. Kean, A. J.; Littlejohn, D.; Ban-Weiss, G. A.; Harley, R. A.; Kirchstetter, T. W.; Lunden, M. M., Trends in on-road vehicle emissions of ammonia. Atmos. Environ. 2009, 43, 1565-1570.

36. Bishop, G. A.; Peddle, A. M.; Stedman, D. H.; Zhan, T., On-road emission measurements of reactive nitrogen compounds from three California cities. Environ. Sci. Technol. 2010, 44, 3616-3620.

37. Port of Long Beach, Clean truck program to be expanded. http://www.polb.com/news/displaynews.asp?NewsID=804\&TargetID=24 (accessed Mar. 2011). 